\title{
Radar glacier zones in southeast Alaska, U.S.A.: field and satellite observations
}

\author{
Joan M. Ramage, ${ }^{1}$ Bryan L. Isagks, ${ }^{1}$ Maynard M. Miller ${ }^{2}$ \\ ${ }^{1}$ Department of Geological Sciences, Cornell University, Ithaca, New York 14853, U.S.A. \\ ${ }^{2}$ Glaciological and Arctic Sciences Institute, University of Idaho, Moscow, Idaho 83844, U.S.A.
}

\begin{abstract}
The ability of synthetic-aperture radar (SAR) to record change in glaciers and icefields on seasonal to interannual time-scales is useful in maritime mountain regions where visible data are often obscured by clouds. A time series of RADARSAT and second European Remote-sensing Satellite (ERS-2) SAR images shows dramatic changes related to the onset and progression of glacier melting on the Juneau Icefield, southeast Alaska, U.S.A. Four "radar glacier zones" are interpreted from SAR images as snow that is dry during winter, an early snowmelt (M), a second phase of snowmelt (M2) and bare ice. These zones develop every year on the Juneau Icefield and other mid-latitude glaciers. Summer field observations on the Juneau Icefield during 1997 and 1998 constrain interpretations of the $\mathrm{C}$-band radar glacier zones. Of the two zones that occur in melting snow (M, M2), $\mathrm{M}$ has low radar backscatter coefficients $\left(\sigma^{\circ}<-12\right)$, in contrast to the higher backscatter coefficients $\left(\sigma^{\circ}>-12\right)$ of the subsequent M2 zone. Snow moisture and surface roughness at the scale of the radar wavelength $(5.6 \mathrm{~cm})$ were measured to characterize the melt zones. Correlation length, wetness and grain-size in the two zones are not distinguishable in the late ablation season. Mean surface roughness, due to the presence of suncups, is higher in the M2 zone than in the M zone and probably causes the higher backscatter due to greater scattering.
\end{abstract}

\section{INTRODUGTION}

Glacier mass balance, the difference between the net snow accumulation and net ice loss over 1 year, is the parameter by which changes in glacier volume are measured. Both the accumulation and the ablation are products of the local weather. We focus here on ablation: the seasonal progression of glacier melting as revealed by synthetic-aperture radar (SAR) images, the near-surface melting characteristics that define two distinct radar glacier zones, and complications imposed by weather events upon the seasonal signal.

Visible wavelengths have great limitations in monitoring frequently cloudy regions such as southeast Alaska, U.S.A. In contrast, SAR is capable of imaging the surface in spite of clouds and darkness, and hence allows repeated imaging of the glacier surface. Understanding the way SAR portrays the glacier surface is a necessary step toward using a multitemporal approach to characterizing or even measuring glacier ablation. We find that radar glacier zones are not restricted to the Patagonian icefields, Chile and Argentina (Forster and others, 1996), and the Stikine icefields, British Columbia, Canada (Smith and others, 1997), where they have been previously observed. We use field measurements of glaciological parameters that influence radar backscatter to characterize two radar glacier zones. Field observations of snow wetness, grain-size and surface roughness were taken on the same dates as 14 SAR images and are used to determine which parameters cause the dif- ferences between the M and M2 radar glacier zones in the mid- to late ablation season on the Juneau Icefield.

The Juneau Icefield is an icefield in southeast Alaska $\left(58^{\circ} 40^{\prime} \mathrm{N}, 134^{\circ} 15^{\prime} \mathrm{W}\right)$, a heavily glaciated mid-latitude region where details of glacier volumes and their changes are poorly known (Dyurgerov and Meier, 1997b). According to Dyurgerov and Meier (1997a), the Coast Range is one of a few glacierized regions (excluding the Greenland and Antarctic ice sheets) that may contribute to global sea-level rise more substantially than would be inferred from its glacier area, due to its high volume and interannual variability of precipitation and ablation. There is a tremendous moisture flux throughout the year. Many tidewater and non-tidewater glaciers in the region have been observed to be shrinking over the past century (e.g. Hall and others, 1995a), with possibly accentuated changes in the 1970s and 1980s (Dyurgerov and Meier, 1997b).

The Juneau Icefield covers $>1000 \mathrm{~km}^{2}$ (Figs 1 and 2). Because of its proximity to Juneau and the established research facilities of the Juneau Icefield Research Program (JIRP), it serves as an ideal site for combined field and satellite observation of the glaciers. Mass-balance and meteorological studies have been conducted on the Juneau Icefield by one of the authors (M.M.M.) and his colleagues since 1946 (Pelto and Miller, 1990). Unlike many of the other glaciers in the region, Taku Glacier is advancing and has had positive mass balance for most of the recent half-century (Pelto and Miller, 1990). The long-term observations make it possible to place radar analyses in the context of historic climate changes. 
Knowledge gained from this site can be applied with care to other mid-latitude glacierized regions.

\section{RADAR GLAGIER ZONES ON MID-LATITUDE GLACIERS}

A melt zone and other zones with coherent radar characteristics have been observed on mountain glaciers and ice sheets (Fahnestock and others, 1993; Forster and others, 1996, 1997; Smith and others, 1997; Partington, 1998). However, the radar glacier zones described here are not the same as glacier facies that have been described in the field and on SAR images of the Greenland ice sheet and Mount Wrangell (e.g. Benson, 1968; Fahnestock and others, 1993; Benson, 1996; Partington, 1998). Glacier facies are the dry-snow facies, the percolation facies, the wet-snow facies and the ice facies. The dry-snow facies does not occur on mid-latitude glaciers except at very high altitudes such as at the peak of Mount Wrangell in the Wrangell-St Elias Mountains (e.g. Benson, 1968; Partington, 1998). All four of the radar glacier zones occur in the wet-snow and ice facies on the Juneau Icefield. Radar glacier zones provide the means to observe dynamic changes in snow-surface properties at elevations that are sensitive to meteorological influences.

Radar glacier zones were first described by Forster and others (1996) on the Patagonian icefields in the Argentina/ Chile Andes (at $\sim 48^{\circ} \mathrm{S}$ ) using multi-band SIR-C/X-SAR data. They are regions on mid-latitude glaciers that display a sequence of SAR backscatter coefficients due to seasonally evolving surface properties. Similar C-band radar features have been observed on other mid-latitude glaciers in Alaska and British Columbia, including glaciers in the Copper River area and the Stikine icefields (Smith and others, 1997) (Fig. 1).

Recent SAR observations of glaciers have shown that the radar backscatter coefficient is sensitive to changing glacier surface properties such as the scale of roughness and the snow wetness (e.g. Rott and Nagler, 1994; Shi and Dozier, 1995; Smith and others, 1997). The spatial and temporal position of the zones with respect to each other is necessary to identify the surface characteristics realistically. Each SAR time series (using second European Remote-sensing

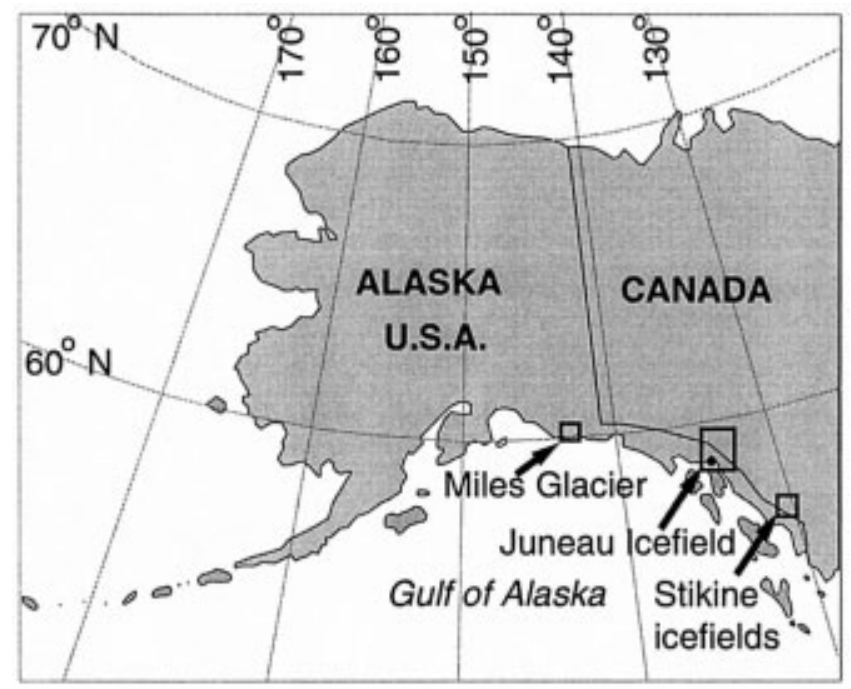

Fig. 1. Site location map. Taku Glacier, site of the field research, is the primary outlet glacier of the Funeau Icefield, on the Alaska-British Columbia boundary. The Stikine icefields and Miles Glacier also develop similar radar glacier zones on a seasonal basis. The black dot marks the location of Funeau.
Satellite (ERS-2) and the Canadian RADARSAT satellite data) shows four discrete regions on mountain glaciers that change with both altitude and time. In Alaska and British Columbia, the four zones were interpreted as frozen winter snow $(\mathrm{F})$, melting snow $(\mathrm{M})$, a second phase of melting snow (M2) (the zone called "P2" by Smith and others, 1997) and bare ice. Smith and others (1997) observed a seasonal trend in radar glacier zones on the Twin Glaciers, Stikine icefields; the seasonal progression of radar glacier zones also occurs on Miles Glacier, Alaska, and on the Juneau Icefield. However, neither the surface characteristics responsible for backscatter zonation nor the regional and temporal distribution of these glacier surface characteristics in Alaska or in other mountain systems has been defined. Once the surface characteristics of C-band radar glacier zones are defined, they can be used to study and understand seasonal and interannual changes on mid-latitude glaciers. Two seasons of field observations in conjunction with SAR data acquisitions were undertaken for this study. These measurements define the surface properties that cause the changing SAR backscatter signatures. A description of each of the four radar glacier zones is followed by analysis of the field characteristics of the two significant melt zones. The results pertain specifically to C-band SAR.

\section{Satellite observations}

\section{Data acquisition and processing}

SAR data were acquired at the Alaska SAR Facility (ASF) in Fairbanks from ERS-2 and RADARSAT. Images were processed at one look in range for four looks in azimuth. Resolution is $25 \mathrm{~m}$ for ERS-2 and RADARSAT standard beam 2 images. RADARSAT ScanSAR images have $100 \mathrm{~m}$ resolution. Both sensors operate at C-band wavelength $(5.6 \mathrm{~cm})$. Radiometric calibration for all data used the ASF Science Technology and Education Program (STEP) software. All ERS-2 and RADARSAT standard beam data were also terrain-corrected using the $1^{\circ}$ U.S. Geological Survey (USGS) digital elevation model (DEM) which has a 3 arcsecond (latitude) by 6 arcsecond (longitude) elevation grid. The vertical accuracy is $\pm 30 \mathrm{~m}$ (USGS, unpublished information, http:// edc.usgs.gov/Webglis/glisbin/guide.pl/glis/hyper/guide/usgsdem). Elevation data were over-sampled to a $30 \mathrm{~m}$ grid to maintain the SAR resolution during processing. This procedure is useful for comparing sequences of images with different imaging geometry, and is crucial for accurately mapping field sites on the SAR images.

RADARSAT and ERS-2 data can be used together effectively to improve the observation frequency. In order to test sensor compatibility we compared two pairs of images that were acquired in close succession by different satellites. Each pair consisted of one ERS-2 image and one RADARSAT standard beam 2 image. The comparison helps to evaluate the validity of combining these datasets. All four images were taken in descending orbits. The images in each pair look very similar to each other. We measured the differences between images in each pair by comparing average backscatter coefficients on a $1 \mathrm{~km}$ wide transect down Taku Glacier (see transect 1-la in Fig. 2 for location). Figure 3 shows the differ-ences between both the 21 and 23 July 1997 and two 25 July 1998 ERS-2 and RADARSAT image pairs (see Table 1 for acquisition times). The average $\sigma^{\circ}$ differences between the two images in each pair are 0.05 (1997) and -0.01 (1998). The low difference values indicate that there are no systematic back- 


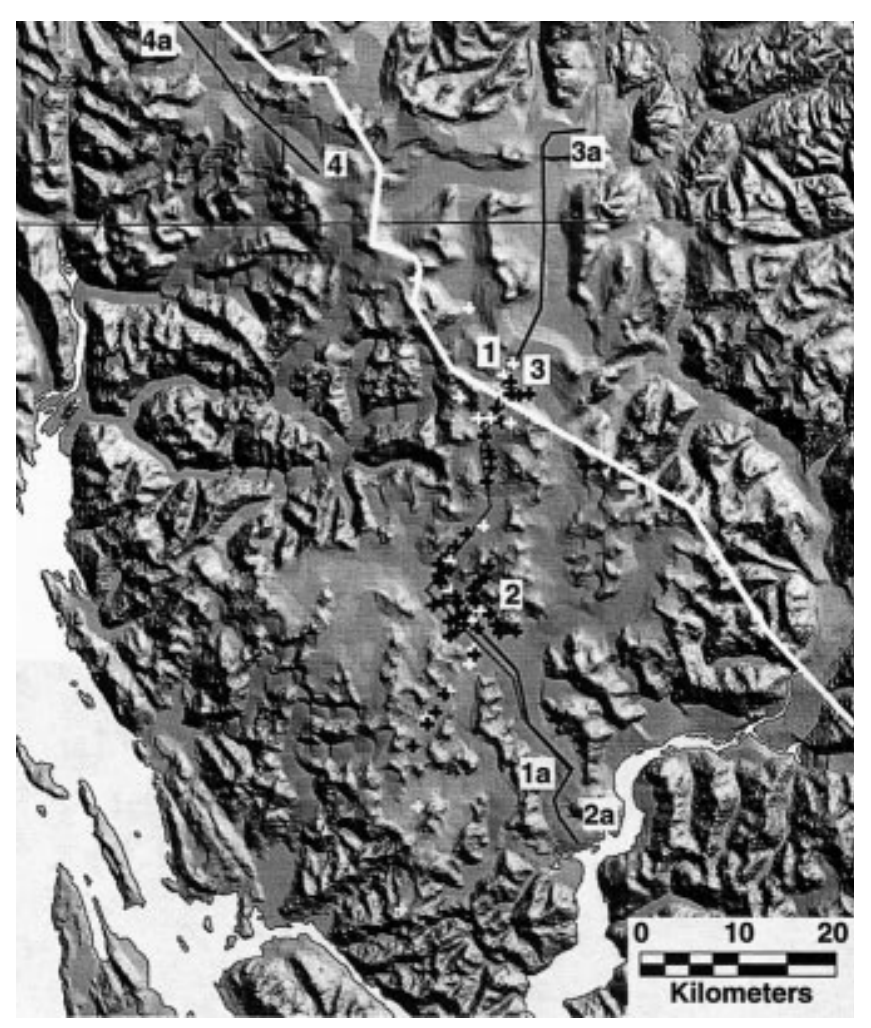

Fig. 2. Shaded relief map of the Juneau Icefield from a $1^{\circ} \mathrm{DEM}$ derived from the USGS and Canadian Topographic Survey 1:250 000 maps. Elevations are on a 3 arcsecond (latitude) by 6 arcsecond (longitude) grid. 1997 (white) and 1998 (black) field sites are shown as pluses. The heavy white line represents the U.S.A.-Canada border. Dashed line (1-1a) is the location of backscatter transects shown in Figures 3 and 7. Solid lines $(2-2 a, 3-3 a, 4-4 a)$ are the transects shown in Figure 6.
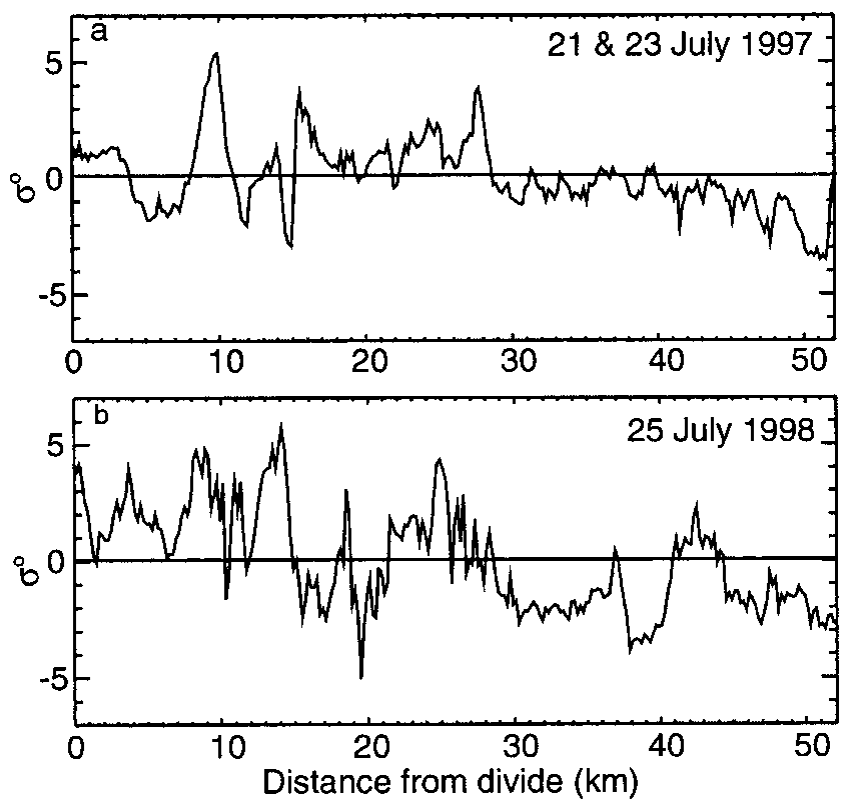

Fig. 3. Differences between 21 and 23 July 1997 (top) and 25 July 1998 (bottom) ERS-2 minus RADARSAT backscatter coefficient transects across the Juneau Icefield. Mean (absolute value) differences in backscatter coefficient are 1.17 (1997 pair) and 1.80 (1998 pair). The mean differences are 0.05 (1997) and -0.01 (1998), showing a lack of bias in the satellite observations.

scatter differences between sensors, but because fluctuating positive and negative values cancel each other out, they do not give the average magnitude of the backscatter difference. Thus, we also measured the absolute value of the difference for each pair. The average absolute values of the backscatter coef-

Table 1. Data used for this study

\begin{tabular}{|c|c|c|c|c|c|c|}
\hline Mission & Band./Pol. & Orbit & Frames $^{\dagger}$ & Date (GMT) & Time (GMT) & Time (Local) \\
\hline ERS-2 & $\mathrm{C} / \mathrm{VV}$ & 9250 & 147 & 26 Jan. 1997 & 0651 & $2151^{*}$ \\
\hline ERS-2 & $\mathrm{C} / \mathrm{VV}$ & 10252 & 147 & 06 Apr. 1997 & 0651 & $2151^{*}$ \\
\hline ERS-2 & $\mathrm{C} / \mathrm{VV}$ & 10274 & 303 & 07 Apr. 1997 & 2002 & 1102 \\
\hline ERS-2 & $\mathrm{C} / \mathrm{VV}$ & 10546 & 303 & 26 Apr. 1997 & 2005 & 1105 \\
\hline ERS-2 & $\mathrm{C} / \mathrm{VV}$ & 11004 & 304 & 28 May 1997 & 1959 & 1059 \\
\hline ERS-2 & $\mathrm{C} / \mathrm{VV}$ & 11276 & 302,304 & 16 Jun. 1997 & 2002 & 1102 \\
\hline RADARSAT S2 & $\mathrm{C} / \mathrm{HH}$ & 8619 & 302 & 29 Jun. 1997 & 1529 & 0629 \\
\hline ERS-2 & $\mathrm{C} / \mathrm{VV}$ & 11505 & 302,304 & 02 Jul. 1997 & 1959 & 1059 \\
\hline RADARSAT S2 & $\mathrm{C} / \mathrm{HH}$ & 8740 & 146,147 & 08 Jul. 1997 & 0224 & $1724^{*}$ \\
\hline ERS-2 & $\mathrm{C} / \mathrm{VV}$ & 11777 & 302,304 & 21 Jul. 1997 & 2002 & 1102 \\
\hline RADARSAT S2 & $\mathrm{C} / \mathrm{HH}$ & 8962 & 302,304 & 23 Jul. 1997 & 1529 & 0629 \\
\hline RADARSAT S2 & $\mathrm{C} / \mathrm{HH}$ & 9083 & 146,147 & 01 Aug. 1997 & 0224 & $1724^{*}$ \\
\hline RADARSAT S2 & $\mathrm{C} / \mathrm{HH}$ & 9426 & 146,147 & 25 Aug. 1997 & 0224 & $1724^{*}$ \\
\hline RADARSAT S2 & $\mathrm{C} / \mathrm{HH}$ & 12735 & 302,304 & 13 Apr. 1998 & 1529 & 0629 \\
\hline RADARSAT S2 & $\mathrm{C} / \mathrm{HH}$ & 13078 & 302,304 & 07 May 1998 & 1530 & 0630 \\
\hline RADARSAT S2 & $\mathrm{C} / \mathrm{HH}$ & 13421 & 302,304 & 31 May 1998 & 1530 & 0630 \\
\hline RADARSAT S2 & $\mathrm{C} / \mathrm{HH}$ & 13864 & 302,304 & 01 Jul. 1998 & 1525 & 0625 \\
\hline RADARSAT S2 & $\mathrm{C} / \mathrm{HH}$ & 13885 & 146,148 & 03 Jul. 1998 & 0224 & $1724^{*}$ \\
\hline ERS-2 & $\mathrm{C} / \mathrm{VV}$ & 16787 & 302,304 & 06 Jul. 1998 & 2002 & 1102 \\
\hline RADARSAT SWB & $\mathrm{C} / \mathrm{HH}$ & 13964 & 301 & 08 Jul. 1998 & 1521 & 0621 \\
\hline RADARSAT SWB & $\mathrm{C} / \mathrm{HH}$ & 14007 & 300 & 11 Jul. 1998 & 1534 & 0634 \\
\hline RADARSAT SWB & $\mathrm{C} / \mathrm{HH}$ & 14021 & 302 & 12 Jul. 1998 & 1505 & 0605 \\
\hline RADARSAT S2 & $\mathrm{C} / \mathrm{HH}$ & 14107 & 302,304 & 18 Jul. 1998 & 1530 & 0630 \\
\hline ERS-2 & $\mathrm{C} / \mathrm{VV}$ & 16994 & 146,148 & 21 Jul. 1998 & 0648 & $2148^{*}$ \\
\hline RADARSAT S2 & $\mathrm{C} / \mathrm{HH}$ & 14207 & 302,304 & 25 Jul. 1998 & 1525 & 0625 \\
\hline ERS-2 & $\mathrm{C} / \mathrm{VV}$ & 17059 & 302,304 & 25 Jul. 1998 & 2004 & 1104 \\
\hline
\end{tabular}

*Satellite overpass on previous date (local time).

${ }^{\dagger}$ Frame numbers 146-148 are ascending orbits. Frame numbers 300-305 are descending orbits. 
ficient differences are 1.17 (1997) and 1.88 (1998), with standard deviations of 1.54 and 2.20, respectively. These values are within the $( \pm 2.0 \mathrm{~dB}$ absolute accuracy calculated by the ASF for radiometrically calibrated ERS-1 and -2 images (http:// www.asf.alaska.edu/dataset_documents/ers1_and_ers2_sar. images.html; 18 September 1996). Calibrated RADARSAT data accuracy is expected to be close to ERS-1 values (http://www.asf.alaska.edu/dataset_documents/radarsatl_standard images.html; 15 August 1996). From the lack of systematic offset, we infer that the differences are real, caused by changes during the 2 day interval in 1997 or diurnal variations due to different acquisition times or different polarizations (1997 and 1998). Both ERS-2 and RADARSAT are co-polarized: ERS-2 is vertically polarized and RADARSAT is horizontally polarized. We did the same test on a winter pair of ERS-2 images taken $\sim 37 \mathrm{~h}$ apart in different orbits (ascending and descending). The backscatter coefficient average (absolute value) difference is 1.3, with a standard deviation of 1.4 . We think that the similarity in backscatter coefficients on these transects, and the spatial similarity between images, makes it valid to compare and combine images from the different sensors.

\section{Dry (frozen in winter) snow zone}

The frozen snow zone appears very bright $\left(\sigma^{\circ}=-8\right.$ to -3$)$. It occurs at high elevations in winter before the spring melt (Figs $4 \mathrm{a}$ and $\mathrm{b}$ and 5). This zone is not the dry-snow facies found in parts of Greenland where snow never melts; it is similar to the wet-snow facies in winter where there is seasonal (summer) melting and refrozen layers in the subsurface. On the Juneau Icefield, the snow, even at the highest elevations, contains liquid water every summer. Snow freezes in the fall, and typically persists in the frozen state on the Juneau Icefield until midApril. During the winter season the new snow is transparent to the radar. When there is no liquid water in the snowpack, the SAR penetrates the snowpack. The high backscatter returns observed consistently during the winter (see "F" in Fig. 4a and b) are probably due to volume scattering in the subsurface firn and scattering from refrozen ice and snow layers (Fahnestock and others, 1993; Rees and others, 1995) (Fig. 4a). This is consistent with the SAR observations of the melt facies in winter on the Greenland ice sheet and on Mount Wrangell (Fahnestock and others, 1993; Partington, 1998). This zone has high backscatter coefficients throughout the winter. A comparison of January and April 1997 ERS-2 scenes shows that there is little change on most glaciers over that period (Fig. 6). The plots for the January/April comparison are derived from $1 \mathrm{~km}$ swath averages along transects 2-2a, 3-3a, and 4-4a in Figure 2. Backscatter changes on the accumulation area are $<2 \mathrm{~dB}$ (within one standard deviation), but over the ablation zone there is a slight but perceptible increase in backscatter. This backscatter increase at lower elevations may be due to development of refrozen layers within the snowpack during transient warm spells.

Backscatter coefficient transects on Taku Glacier are also shown for a winter image and subsequent ERS-2 and RADARSAT images during the 1997 melt season (Fig. 7). This sequence of transects shows the radar glacier zone through one melt season. Backscatter coefficients were measured along a transect from high to low elevation on Taku Glacier (transect 1-la in Fig. 2). Each transect is a $1000 \mathrm{~m}$ wide swath average performed on unfiltered SAR data and then smoothed over a $1400 \mathrm{~m}$ window. We have no field observations when the snow was frozen.
Melt ( $M)$ zone

This melt phase replaces the frozen (during winter) snow zone with very low radar backscatter values $\left(\sigma^{\circ}=-25.5\right.$ to -12$)$ (see "M" in Fig. 4b; see also Fig. 5). The melt zone (M) is illustrated for the Juneau Icefield in spring 1998 (Fig. 4b and c). The RADARSAT images in Figure 4 were acquired in the same track and look direction and at the same time of day, so diurnal and geometric variations are minimal. Between April and late May or mid-June, the backscatter coefficients are typically very low, for some areas returning a signal below the noise level (Fig. 4c). This dramatic radar signature of the melt zone systematically migrates from lower to higher altitudes as the melting progresses in response to spring warming (Fig. 8; Smith and others, 1997).

We compared the radar glacier zone boundaries in 1997 to the mean daily $0^{\circ} \mathrm{G}$ isotherm based on maximum and minimum temperatures recorded at the nearby Juneau Airport. The elevation of the $0^{\circ} \mathrm{C}$ isotherm was calculated based on a lapse rate of $-6.5^{\circ} \mathrm{C}(1000 \mathrm{~m})^{-1}$. Zone boundaries were mapped on ERS-2 and RADARSAT images, and elevations were extracted using the USGS $30 \mathrm{~m}$ DEM (boundary elevations are shown as gray dots in Figure 8). The frozen-snow zone has a stable winter SAR signature (Figs 6 and 8). The melt phase parallels the spring warming, and in 1997 the top of the melt zone correlated reasonably well with the elevation of the mean daily $0^{\circ} \mathrm{C}$ isotherm. Note that the elevation of the boundary between the melt phase and phase 2 melt zone fluctuates. The drop in that boundary on 7 July was probably due to a record-breaking July rainfall on 6 July 1997 (5.2 cm of rain were recorded in Juneau). The upper boundary of the melt zone tends to follow a contour, and it is commonly (not exclusively) controlled by increases in temperature (Fig. 8).

\section{Phase 2 melt ( M2) zone}

The initial wet-snow phase is followed by a bright phase $\left(\sigma^{\circ}=-7.5\right.$ to -3$)$ that is also associated with melting and is interpreted as a second-stage snowmelt (Figs 4d and 5). The brightness of the return has previously been attributed to either a roughening of the surface or metamorphosis of the snow (Smith and others, 1997). Our field experiments determine that suncups (higher-relief undulations in three dimensions) cause the high backscatter of the phase 2 melt zone. For wet-snow conditions, surface roughness at the scale of the radar wavelength contributes to a higher-magnitude backscatter coefficient. Throughout the summer, the snow is wet in both the M and M2 zones, but the surface relief at the radar scale is greater in the M2 zone. When the wetness increases beyond $3 \%$ by volume, surface scattering on the roughened surfaces causes an increase in backscatter (Ulaby and others, 1982; Shi and Dozier, 1995; Hall, 1996). This surface scattering off the roughened surface is thought to be the cause of the M2 melt zone. Overall, smooth, wet surfaces (M) have low backscatter, and rough, wet surfaces (M2) have higher backscatter. However, a complex relationship makes it difficult to extract a simple correlation (Shi and Dozier, 1995). For more details, see the discussion of field observations below.

\section{Bare ice and old firn}

Once the snow melts on the surface of the glacier, the exposed bare ice and firn appear darker $\left(\sigma^{\circ}=-12\right.$ to -10$)$ than the preceding M2, but brighter than the very dark initial snowmelt (M) (Figs 4d and 5). Bare ice is a specular reflector, causing low backscatter returns. Surface features such as crevasses 

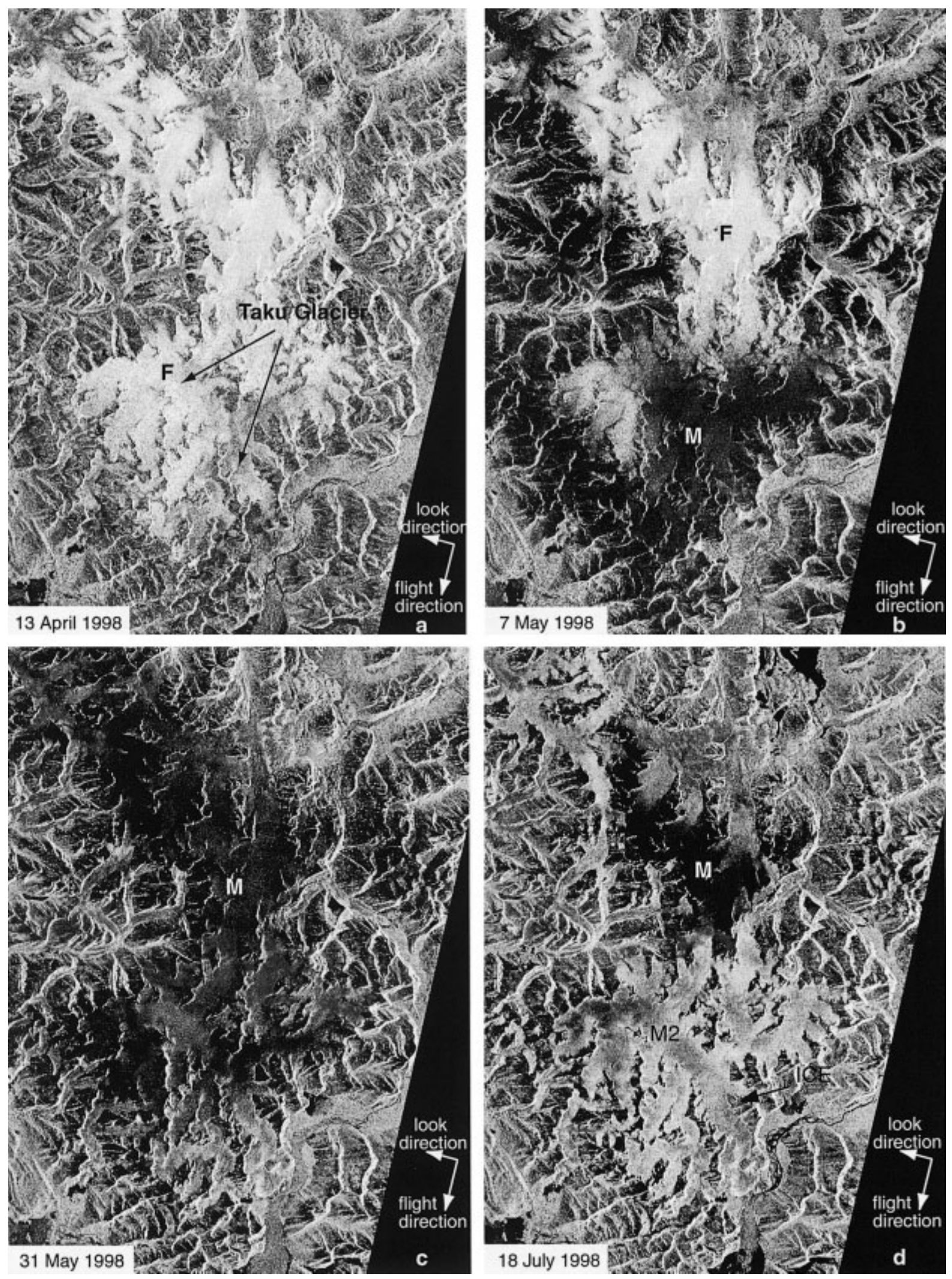

Fig. 4. Sequence of 1998 RADARSATstandard beam 2 images of the funeau Icefield, showing radar glacier zone development from winter to mid-summer. The images were radiometrically calibrated $\left(\sigma^{\circ}=0\right.$ to-25.5), and were acquired at the same time of day and with the same orbit geometry, thus minimizing diurnal and geometric effects. F, frozen; $M$, initial melt; M2, phase 2 melt; Ice, bare ice. Images (C) Canadian Space Agency (CSA) 1998.

and moraines become clearly visible because of their roughness relative to the C-band wavelength. During the late summer, this zone includes areas of exposed multi-year firn above the ice-firn boundary. In winter, a firn line is visible beneath the new snow accumulation, whereas in the summer it is difficult to distinguish ice from multi-year firn (Lingle and others, 1992; Hall and others, 1995b).

\section{Field observations of melt zones}

We refine interpretations of the radar glacier zones by comparing surface parameters observed in situ on the Juneau Icefield with ERS-2 and RADARSAT SAR backscatter coefficient sequences. Field measurements of the glacier surface can discriminate the physical processes 


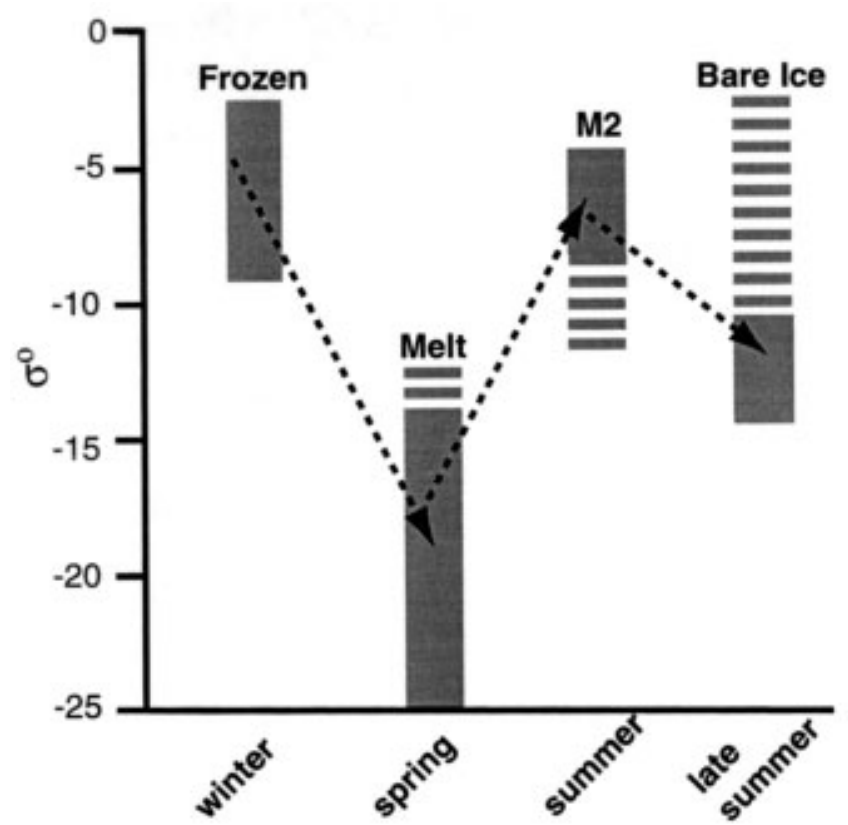

Fig. 5. Schematic diagram of backscatter changes through the melt season. Timing of zone development varies from year to year. Solid gray areas represent dominant range of values for each zone. Dashed areas indicate extended range of values.

Backscatter coefficients between zones are transitions.

dominating the radar backscatter in the initial melt (M) and second melt (M2) zones. We observed these properties contemporaneously with 14 satellite overpasses during two summers $(1997,1998)$ on the Juneau Icefield.

Backscatter is sensitive to snow surface roughness at the

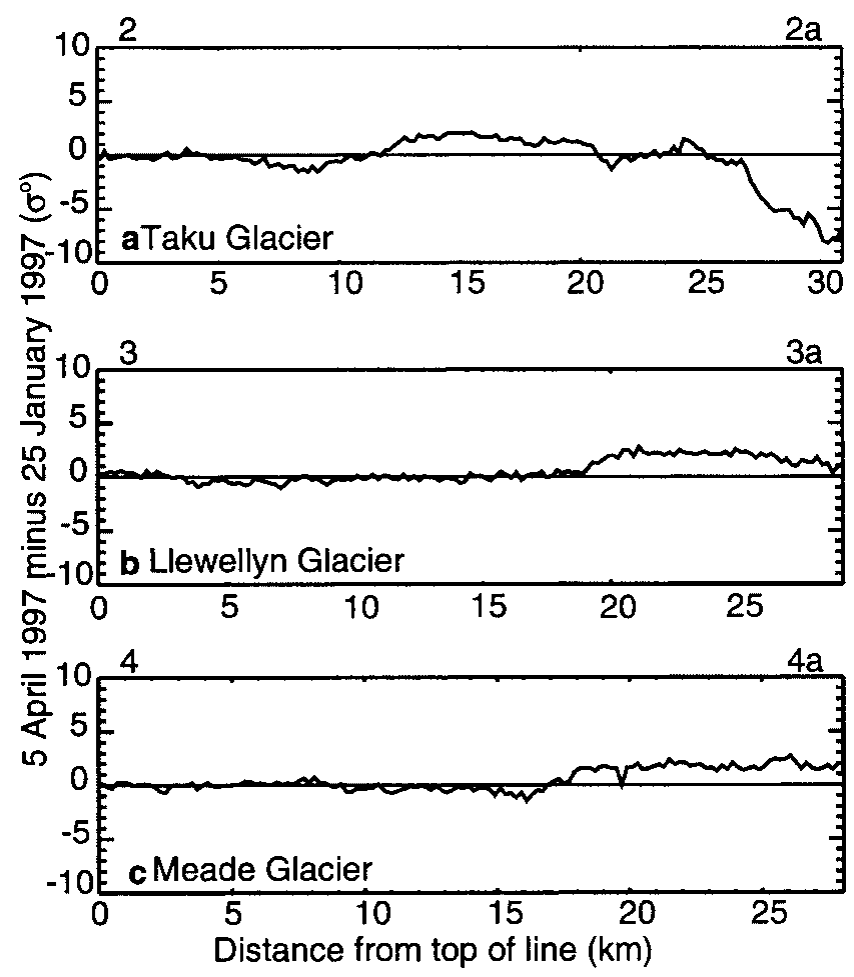

Fig. 6. Backscatter differences for 5 April 1997 minus 25 January 1997. See Figure 2 for transect locations. In all plots elevation decreases from left to right. High-elevation areas on the funeau Icefield show relatively little change in backscatter coefficient between Fanuary and April. Areas below the approximate firn line show a 2-3 increase in $\sigma^{\circ}$. Low-elevation areas on Taku Glacier and river valleys have already started to melt, so there is a large backscatter contrast (e.g. see right side of transect 2-2a).
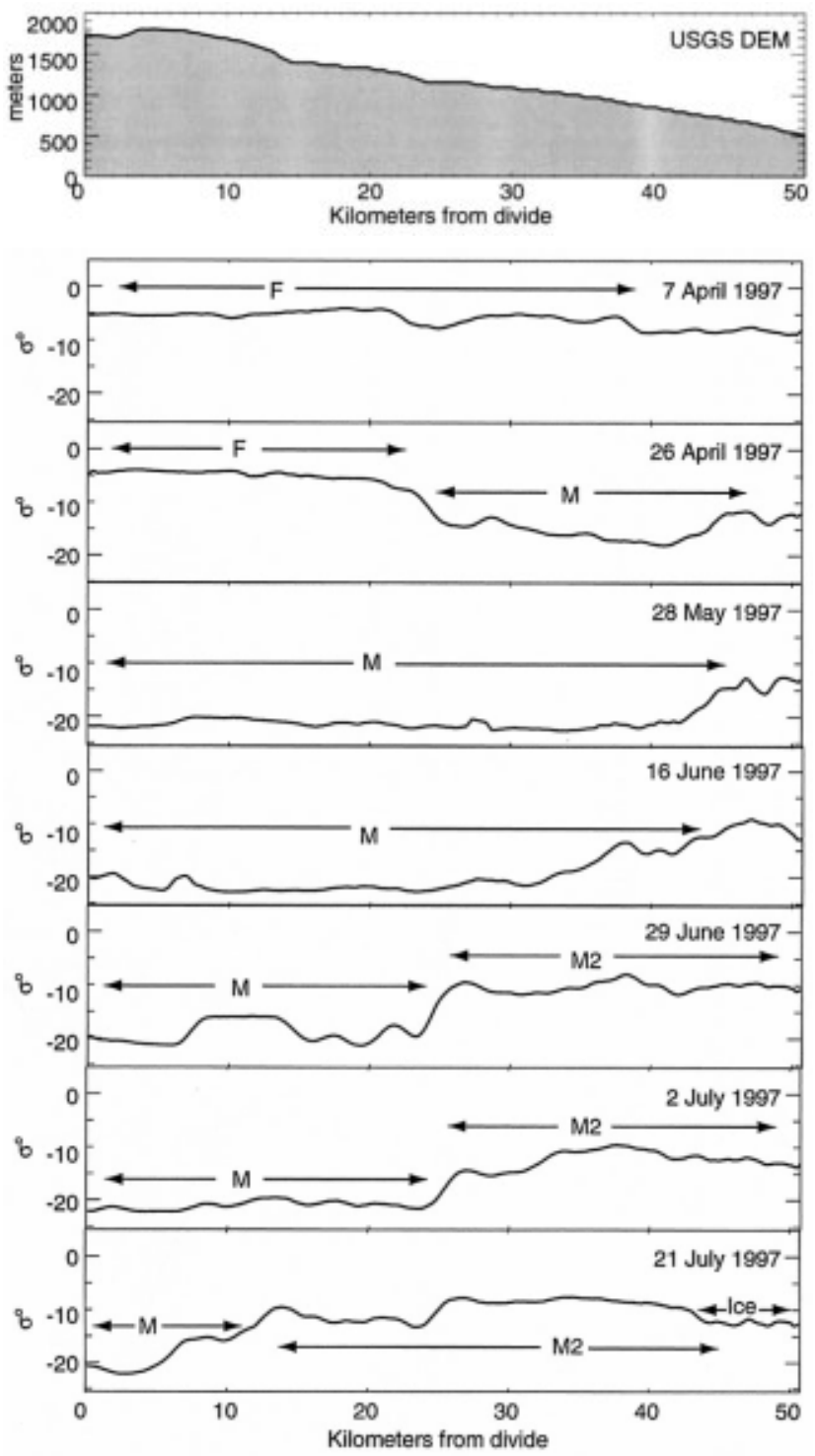

Fig. 7. Seasonal sequence of backscatter coefficients down Taku Glacier along transect 1-1a. Transect location is shown in Figure 2. Shaded area in the top graph shows topography along the transect. Pixel backscatter coefficients were averaged across the $1000 \mathrm{~m}$ transverse width of the profile and then smoothed over $1400 \mathrm{~m}$ along the profile to focus on lower-frequencey changes. All swath averages shown were taken on descending orbit passes.

scale of the radar wavelength, liquid moisture near the snow surface, grain-size and subsurface structures. It is the surface roughness in the mid- to late ablation season that contributes to the high backscatter of the M2 zone. The effect of other factors, such as the free-water content of the snow, is important early in the season, but becomes less important once the snow is sufficiently wetted and the surface morphology develops due to ablation.

Grain-size and ice lenses

Aged snow grains are uniform spheroidal shapes with diameters of 1-2 mm. The spatial uniformity makes it unlikely that grain-size is the factor dominating backscatter differences. Ice lenses are important during the winter months, causing backscatter from structures within frozen snow, but because liquid water strongly attenuates subsurface penetration, ice lenses and other structures are not significant during the summer when the snow surface is wet. The following subsections focus on the roughness and wetness contributions to the SAR backscatter coefficient. 


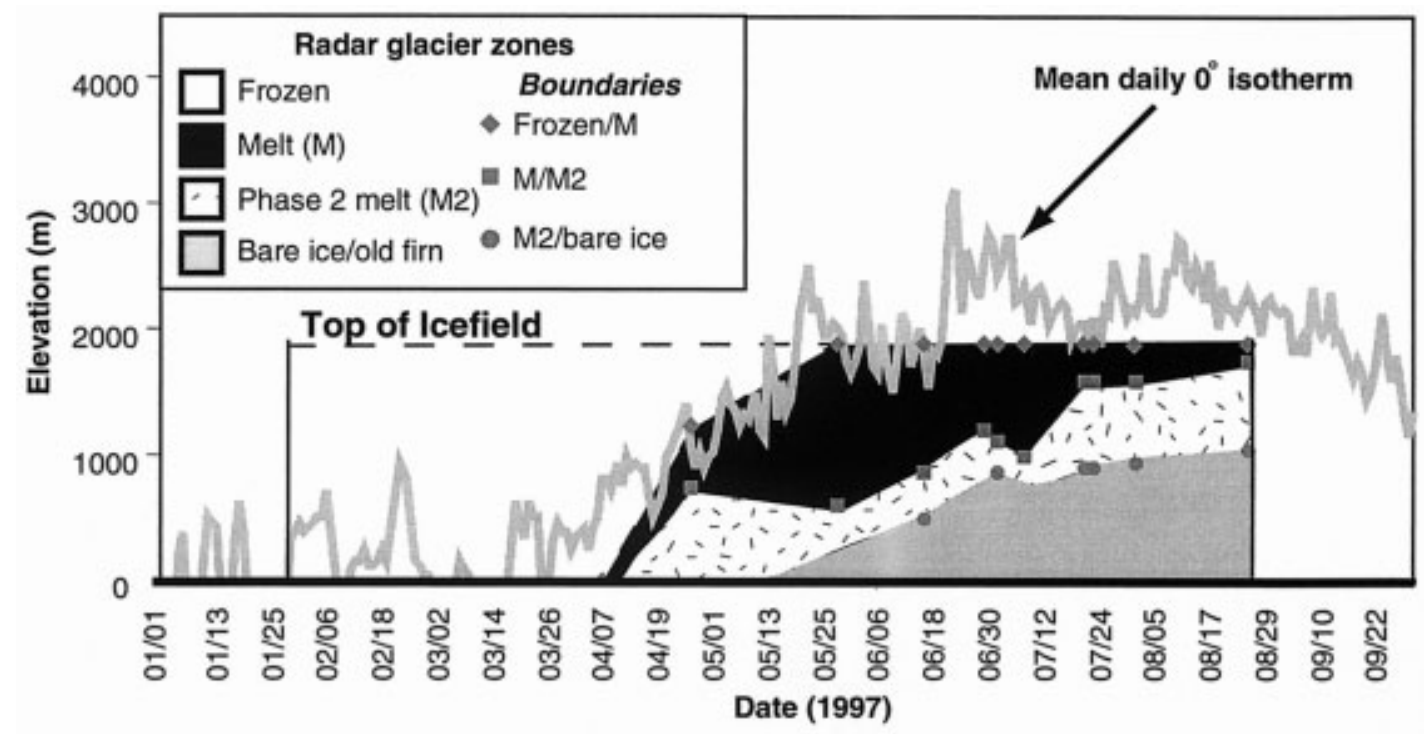

Fig. 8. Progression of radar glacier zones based on 1997 SAR sequence. Shaded regions show development with elevation and time (covering one melt season) and the relationship to temperature. The mean daily $0^{\circ} \mathrm{C}$ isotherm is based on the average of the daily maximum and minimum recorded temperatures in funeau and a lapse rate of $-6.5^{\circ} \mathrm{C}(1000 \mathrm{~m})^{-1}$. Boundary positions are accurate to within $\sim 200 \mathrm{~m}$. Dates are in $\mathrm{mm} / \mathrm{dd}$.

\section{Surface roughness}

To measure glacier surface roughness on the Juneau Icefield at scales near the C-band SAR wavelength $(5.6 \mathrm{~cm})$, we photographed the snow-surface profile using a $2 \mathrm{~m}$ "roughness plate" oriented perpendicular to the surface. The photographs were digitized, then cropped to include only the black plate and snow profile, then converted to a binary image using a threshold value that represents the snow-air boundary appropriately (threshold values varied due to different light conditions). Some examples are shown in Figure 9. The image of the snow-surface profile was vectorized to a function and analyzed for correlation length and standard deviation of the roughness height. The calculations are based on the discussion in Ulaby and others (1982).

The standard deviation of the surface-roughness height compares the surface to a reference surface, calculated as the mean horizontal line in our two-dimensional samples. Also evaluated was the maximum surface height for each sample, defined as the absolute value of the maximum deviation from the mean. Two to eight (usually four) roughness observations were taken at each of 78 sites on Taku Glacier (locations are shown in Figure 2).

Surface-height standard deviations range from $<1$ to $6.6 \mathrm{~cm}$, and maximum surface heights range up to $13 \mathrm{~cm}$. Surface-roughness heights on the high-altitude "divide" area (>20 sites) are, on average, lower than they are at lower altitudes on Taku Glacier (Fig. 9). Mean surface-roughness standard deviation for the $\mathrm{M}$ zone is $18.9 \mathrm{~mm}$ compared to $28.1 \mathrm{~mm}$ for the M2 melt zone (all 1997 and 1998 data). Histograms of roughness distributions for each melt zone show that they have similar ranges; however, the low-backscatter regions tend to have smoother surfaces (Fig. 10a; Table 2). A $t$ test shows that the two groups of samples (M and M2) are distinct at the $82 \%$ significance level.

The correlation length was calculated for each snowsurface profile based on Ulaby and others (1982). Correlation lengths for all measurements range from $<10$ to $>100 \mathrm{~cm}$, with $86 \%$ of them falling below $40 \mathrm{~cm}$ (Fig. 10b; Table 3). The average correlation length is $23 \mathrm{~cm}$. The correlation lengths do not show any pattern relating to site location, roughness height or backscatter, suggesting that correlation length is not a diagnostic characteristic for radar glacier zones on the Juneau Icefield. The correlation lengths are not statistically different. Thus, it is likely that the higher-amplitude surface on the lower Taku Glacier in the M2 zone provides the facets creating the high backscatter coefficients seen on the SAR images.

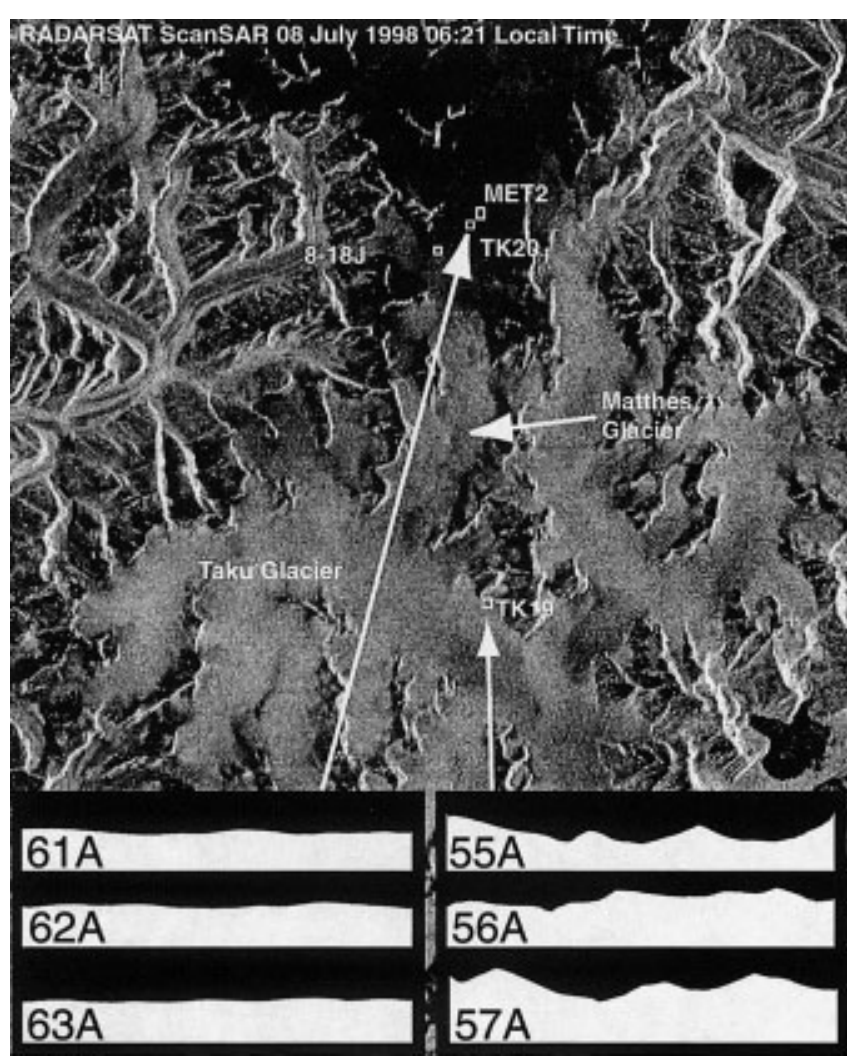

Fig. 9. RADARSAT ScanSAR image of Taku Glacier showing backscatter coefficient and surface-roughness profile for the lower Taku (TK9) and the upper Matthes (TK20, MET2, 8-187) Glaciers. Note the correspondence between smooth surfaces and low (dark) backscatter and undulating surfaces and high (bright) backscatter. Each sample length is $2.0 \mathrm{~m}$. The image was acquired on 8 fuly 1998 at $0621 \mathrm{~h}$ local time. Image (C) CSA. 

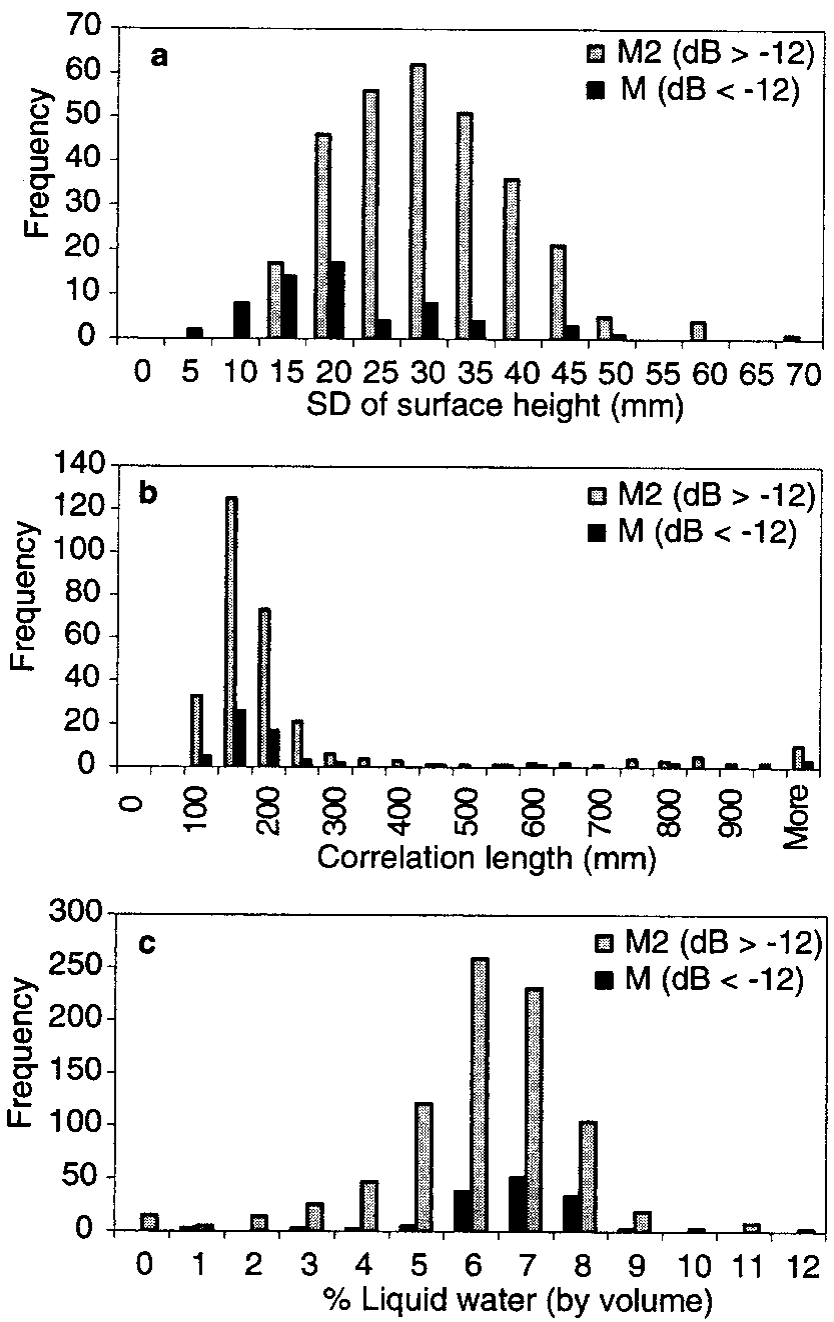

Fig. 10. Histograms of (a) surface roughness, (b) correlation length and (c) wetness. In each case the histogram compares the characteristics of the glacier surface for the $M$ and $M 2$ zones. For separating the two groups of field observations, the sites were distributed based on whether the mean backscatter coefficient $\left(\sigma^{\circ}\right)$ was above-12 (M2) or below-12 (M).

Surface wetness

One of the prominent surface changes observable by C-band SAR is the initiation of melting within the glacier snow cover (Mätzler and Schanda, 1984; Rango, 1993). The increase in

Table 2. Comparison of surface roughness $(\mathrm{mm})$ for $M$ and M2 zones

\begin{tabular}{ccc}
\hline Year & Melt $(M)$ zone & Melt phase 2 (M2) zone \\
\hline & Mean & Mean \\
1997 & $13.1(19)$ & $24.8(26)$ \\
1998 & $21.5(42)$ & $28.4(273)$ \\
All & $18.9(61)$ & $28.1(299)$ \\
& Minimum & Minimum \\
1997 & 4.0 & 12.2 \\
1998 & 6.3 & 10.1 \\
All & 4.0 & 10.1 \\
& Maximum & Maximum \\
1997 & 33.5 & 44.4 \\
1998 & 47.2 & 66.4 \\
All & 47.1 & 66.4 \\
& & \\
\hline
\end{tabular}

Note: Numbers in parentheses represent the number of measurements taken.
Table 3. Comparison of correlation length ( $\mathrm{mm}$ ) for $M$ and M2 zones

$\begin{array}{ccc}\text { Year } & \text { Melt }(\text { M) zone } & \text { Melt phase 2(M2) zone } \\ & \text { Mean } & \text { Mean } \\ 1997 & 165(19) & 203(26) \\ 1998 & 265(42) & 232(273) \\ \text { All } & 234(61) & 230(299) \\ & \text { Minimum } & \text { Minimum } \\ 1997 & 69 & 58 \\ 1998 & 102 & 78 \\ \text { All } & 69 & 58 \\ & \text { Maximum } & \text { Maximum } \\ 1997 & 780 & 860 \\ 1998 & 1251 & 1314 \\ \text { All } & 1251 & 1314\end{array}$

Note: Numbers in parentheses represent the number of measurements taken.

liquid water in the snowpack ( $\sim 2 \%$ by volume) causes more specular reflection and less signal penetration in the snowpack (Jezek and others, 1993; Shi and Dozier, 1995). Liquid water in the snowpack increases the absorption coefficient (Ulaby and others, 1982; Shi and Dozier, 1995; Hall, 1996). Both of these characteristics lead to low backscatter coefficients. The presence of free water in the surface snow is important early in the season during the transition from frozen to melting snow.

Snow liquid-water content near the glacier surface was measured during the two melt seasons using a snow-moisture meter that consists of a flat $20 \mathrm{MHz}$ capacitance probe (Denoth, 1989). These measurements determine the dielectric properties of the snow. The dielectric constant (calculated from meter readings) is combined with independent measurements of snow density to calculate the snow wetness (up to $\sim 10 \%$ by volume). Snow wetness was found to be variable in space and time; approximately 20 measurements were taken at each of $\sim 40$ observation sites. Measurements on some sites were repeated on different dates.

Wetness values are 1 to $>8 \%(1997)$ and 4 to $>10 \%$ (1998) for areas in both the M and the M2 zones during July (Table 4). Histograms of all 1998 surface-wetness observations show that both the M and M2 zones are wet and that the wet-

Table 4. Comparison of surface wetness (\%) for Mand M2 zones

\begin{tabular}{ccc}
\hline Year & Melt $(M)$ zone & Melt phase $2($ M2) zone \\
& Mean & Mean \\
1997 & $5.3(19)$ & $3.2(106)$ \\
1998 & $6.3(120)$ & $5.9(748)$ \\
All & $6.2(139)$ & $5.6(854)$ \\
& Minimum & Minimum \\
1997 & $<0.5$ & $<0.5$ \\
1998 & 3.7 & $<0.5$ \\
All & $<0.5$ & $<0.5$ \\
& Maximum & Maximum \\
1997 & 7.9 & 10.1 \\
1998 & 8.8 & 11.7 \\
All & 8.8 & 11.7
\end{tabular}


ness distributions are indistinguishable (Fig. 10c). Results were similar for 1997; therefore, the percentage of liquid water in the snowpack is not a diagnostic characteristic of the late-ablation-season radar glacier zones. No observations were taken early in the initial melting phase, when spatial differences in wetness throughout the snowpack probably influence the backscatter coefficient. Based on these observations, we suggest that once the surface has been sufficiently wetted (beyond $\sim 3 \%$ ), surface scattering is the most important mechanism and the roughness determines the backscatter.

\section{DISGUSSION AND GONGLUSIONS}

Four radar glacier zones, the frozen (during winter) snow zone, the initial melt (M) zone, the phase 2 (M2) melt zone and the bare-ice zone, are defined on the basis of their SAR backscatter coefficients and their spatial and temporal distributions on mid-latitude glaciers. The radar glacier zones exist on numerous mid-latitude glacier systems including glaciers such as the Patagonian icefields in Chile and Argentina, Miles Glacier in the Copper River region of southern Alaska, the Stikine icefields in British Columbia and the Juneau Icefield in southeast Alaska. The progression of radar glacier zones is related to seasonal temperature cycles with boundary fluctuations and backscatter changes also influenced by weather events, including heavy rain, snowstorms, intense radiation or high temperatures, and temperatures below freezing.

Ground-based observations combined with satellite observations from two SAR instruments, ERS-2 and RADARSAT, are used to constrain the interpretations of radar glacier zones. Two summer field seasons were undertaken to study the $\mathrm{M}$ and M2 melt zones on the Juneau Icefield. At the beginning of the melt seasons, the low backscatter coefficients of zone $\mathrm{M}$ are related to an increase in absorption due to moisture in the snowpack and an increase in scattering away from the sensor. As melting increases, liquid moisture increases and the snowpack metamorphoses. Extensive measurements of surface wetness and surface roughness demonstrate that both the $\mathrm{M}$ and the M2 melt zones contain liquid-water content in excess of $3 \%$ most of the time during July and August. By the middle of the ablation season, areas in both zones $\mathrm{M}$ and $\mathrm{M} 2$ are melting, so other surface characteristics dominate the SAR returns. Field observations show roughness-height differences between the low-backscatter M zone and the high-backscatter M2 zone. The roughness differences are due to the development of ablation-related suncups. Other factors that typically influence radar backscatter coefficient are uniform between the two zones; therefore, the roughness difference is likely to be the cause of the amplitude difference. The Juneau Icefield observations show that areas on the glacier with higher roughness tend to have high backscatter $\left(\sigma^{\circ}>-12\right)$, and regions with lower roughness tend to have low backscatter $\left(\sigma^{\circ}<-12\right)$. The high backscatter coefficient of M2 is primarily due to surface scattering over a wet, roughened snow surface, whereas zone $\mathrm{M}$ is smoother and has lower backscatter.

The differences between the M and M2 radar glacier zones are probably enhanced by processes related to surface metamorphosis and suncup development. At the lower elevations where the M2 zone is predominant, the melting starts earlier in the season, the temperatures are higher and there is rarely snowfall in the summer. In contrast, high on the icefield where the $\mathrm{M}$ zone persists well into the melt season, temperatures are cooler, snow starts to melt about a month later and snow may fall sporadically. Intermittent snowfalls at the higher elevations tend to smooth the surface when suncups start to develop. In many cases, the summer snowfall also prevents full M2 development at the highest elevations, where one might expect large suncups to develop late in the melt season.

SAR data are effective for mapping melt onset in heavily glacierized southeast Alaska, and for tracking the melt-zone development over seasons. Knowing the dominant surface characteristics of each of the radar glacier zones and the atmospheric conditions that contribute to their development will permit use of the radar glacier zones and their distributions to assess interannual variability and glacier changes. In the future, observations of the spatial and temporal distribution of melting episodes may be used to evaluate the ablation component of the glacier mass balance.

\section{ACKNOWLEDGEMENTS}

The authors thank the Foundation for Glacier and Environmental Research and the JIRP for providing valuable assistance with the fieldwork. The ASF provided ERS-2 and RADARSAT SAR data and access to software. We thank H. Rott, D. Hall and an anonymous reviewer for their comments. We also thank A. Bloom, R. Davis, D. Hall and A. Klein for helpful discussions and the use of field equipment. This work was supported by a NASA Goddard Space Flight Center Graduate Student Research Program fellowship to J.M.R., NASA EOS (NAG5-6111) and NASA LSHP (NAGS-7497) grants. Fieldwork was supported by the Cornell Department of Geological Sciences, JIRP and Alaska's NASA Space Grant. This is Cornell University Department of Geological Sciences Institute for the Study of the Continents (INSTOG) contribution No. 254.

\section{REFERENGES}

Benson, C. S. 1968. Glaciological studies on Mount Wrangell, Alaska, 1961. Arctic, 21 (3), 127-152.

Benson, C. S. 1996. Stratigraphic studies in the snow and firn of the Greenland ice sheet. SIPRE Res. Rep. 70.

Denoth, A. 1989. Snow dielectric measurements. Adv. Space Res., 9(1), 233-243.

Dyurgerov, M. B. and M. F. Meier. 1997a. Mass balance of mountain and subpolar glaciers: a new global assessment for 1961-1990. Arct. Alp. Res., 29(4), 379-391.

Dyurgerov, M. B. and M. F. Meier. 1997b. Year-to-year fluctuations of global mass balance of small glaciers and their contribution to sea-level changes. Arct. Alp. Res., 29(4), 392-402.

Fahnestock, M., R. Bindschadler, R. Kwok and K. Jezek. 1993. Greenland ice sheet surface properties and ice dynamics from ERS-1 SAR imagery. Science, 262(5139), 1530-1534.

Forster, R. R., B. L. Isacks and S. B. Das. 1996. Shuttle imaging radar (SIR-C/ X-SAR) reveals near-surface properties of the South Patagonian icefield. f. Geophys. Res., 101 (E10), 23,169-23,180.

Forster, R. R., L. C. Smith and B. L. Isacks. 1997. Effects of weather events on X-SAR returns from ice fields: case-study of Hielo Patagónico Sur, South America. Ann. Glaciol., 24, 367-374.

Hall, D. K. 1996. Remote sensing applications to hydrology: imaging radar. Hydrol. Sci. 7., 41 (4), 609-624.

Hall, D. K., C. S. Benson and W. O. Field. 1995a. Changes of glaciers in Glacier Bay, Alaska, using ground and satellite measurements. Phys. Geogr., 16(1), 27-41.

Hall, D. K., R. S. Williams, Jr and O. Sigurðsson. 1995b. Glaciological observations of Brúarjökull, Iceland, using synthetic aperture radar and thematic mapper satellite data. Ann. Glaciol., 21, 271-276.

Jezek, K. C., M. R. Drinkwater, J. P. Crawford, R. Bindschadler and R. Kwok. 1993. Analysis of synthetic aperture radar data collected over the southwestern Greenland ice sheet. F. Glaciol., 39(131), 119-132.

Lingle, C. S., W. D. Harrison and K. Ahlnäs. 1992. Observations of glaciers in 
the St. Elias Mountains, Alaska-YukonTerritory, with synthetic aperture radar. Abstract. In Environmental Change: Natural and Man-Made, AAAS 43rd Arctic Science Conference, 8-12 September 1992, Valdez, Alaska. Program and Proceedings. Fairbanks, AK, University of Alaska. Geophysical Institute, 387.

Mätzler, C. and E. Schanda. 1984. Snow mapping with active microwave sensors. Int. F. Remote Sensing, 5(2), 409-422.

Partington, K.C. 1998. Discrimination of glacier facies using multi-temporal SAR data. 7. Glaciol., 44(146), 42-53.

Pelto, M. S. and M. M. Miller. 1990. Mass balance of the Taku Glacier, Alaska from 1946 to 1986. Northwest Sci., 64(3), 121-130.

Rango, A. 1993. Snow hydrology processes and remote sensing. Hydrol. Processes, 7(2), 121-138.

Rees, W.G., J. A. Dowdeswell and A. D. Diament. 1995. Analysis of ERS-1 synthetic aperture radar data from Nordaustlandet, Svalbard. Int. 7. Remote
Sensing, 16(5), 905-924.

Rott, H. and T. Nagler. 1994. Capabilities of ERS-1 SAR for snow and glacier monitoring in alpine areas. In Space at the Service of our Environment. Proceedings of the Second ERS-1 Symposium, 11-14 October 1993, Hamburg, Germany. Vol. 2. Paris, European Space Agency, 965-970. (ESA SP-361.)

Shi Jiancheng and J. Dozier. 1995. Inferring snow wetness using C-band data from SIR-C's polarimetric synthetic aperture radar. IEEE Trans. Geosci. Remote Sensing, GE-33(4), 905-914.

Smith, L. C., R. R. Forster, B. L. Isacks and D. K. Hall. 1997. Seasonal climatic forcings of alpine glaciers revealed with orbital synthetic aperture radar. 7. Glaciol., 43(145), 480-488.

Ulaby, F. T., R. K. Moore and A. K. Fung. 1982. Microwave remote sensing, active and passive. Vol. 2. Radar remote sensing and surface scattering and emission theory. Reading, MA, Addison-Wesley Publishing Co.

MS received 22 March 1999 and accepted in revised form 30 November 1999 